Research Article

\title{
Ethnoecological, Elemental, and Phytochemical Evaluation of Five Plant Species of Lamiaceae in Peshawar, Pakistan
}

\author{
Sulaiman (iD, ${ }^{1}$ S. M. Shah, ${ }^{2}$ Sadaf, ${ }^{1}$ M. Amin, ${ }^{1}$ B. Gul, ${ }^{1}$ and M. Begum ${ }^{1}$ \\ ${ }^{1}$ Department of Botany, University of Peshawar (UoP), Peshawar, KP 25120, Pakistan \\ ${ }^{2}$ Centre of Plant Biodiversity, University of Peshawar (UoP), Peshawar, KP 25120, Pakistan \\ Correspondence should be addressed to Sulaiman; sulaiman097@uop.edu.pk
}

Received 28 May 2020; Revised 16 July 2020; Accepted 23 July 2020; Published 27 August 2020

Academic Editor: Umit Tursen

Copyright (C) 2020 Sulaiman et al. This is an open access article distributed under the Creative Commons Attribution License, which permits unrestricted use, distribution, and reproduction in any medium, provided the original work is properly cited.

\begin{abstract}
The use of medicinal plants as an unconventional health treatment is gaining considerable recognition and popularity worldwide. The current study was designed to inspect five medicinally important species (such as Mentha longifolia (L.) Huds., Mentha piperita L., Mentha spicata L., Ocimum basilicum L., and Rosmarinus officinalis L.) of Lamiaceae, collected from district Peshawar, through ethnoecological, phytochemical, and elemental analyses. Biological spectra expressed that therophytes (60\%) were the dominant life-form class, while nanophyll (60\%) was the leading class among leaf size. The ethnobotanical profile showed that all the species were medicinal and ornamental (100\%) each, while $60 \%$ were used in spices. Quantitative analysis for the macro- and microminerals confirmed the presence of 13 elements $(\mathrm{C}, \mathrm{N}, \mathrm{O}, \mathrm{Mg}, \mathrm{K}, \mathrm{P}, \mathrm{S}, \mathrm{Ca}, \mathrm{Al}, \mathrm{Si}, \mathrm{Fe}, \mathrm{Cl}$, and $\mathrm{Na}$ ), which were present in varying amounts from species to species. The methanol extract of leaf samples was used for the analysis of phytochemical constituents such as saponins, flavonoids, tannins, terpenoids, phlobatannins, steroids, and anthraquinones. The medicinal potential of these plants was correlated with the presence of these phytochemicals. Due to the presence of active constituents, the plants had high potential in antifungal, antidiuretic, antioxidant, and anti-inflammatory activities.
\end{abstract}

\section{Introduction}

Peshawar is the capital city of Khyber Pakhtunkhwa, province of Pakistan, located at the altitude of 300 meters between $35^{\circ} 50^{\prime} 37 \mathrm{~N}$ latitude and $71^{\circ} 21^{\prime} 45 \mathrm{E}$ longitude (Figure 1). Its population is $1,970,042$, and it covered an area of 1,257 kilometer square [1]. Edaphology deals with the influence of soil on living things specially plants. Peshawar is covered with the combined deposits of sand, silt, and loamy soil, which support a great diversity of flora. Peshawar is not located in the monsoon region unlike the other northern parts of Pakistan. The area has extreme conditions; the coldest month is January with average maximum temperature $18.35^{\circ} \mathrm{C}$, and the hottest month is June having a mean maximum temperature of $40.8^{\circ} \mathrm{C}$. The relative humidity varies from $46 \%$ in June to $76 \%$ in August [2]. The average annual rainfall recorded was $454.2 \mathrm{~mm}$. Plants are used as medicine and food since time immemorial round the globe due to their most valuable properties. Medicinal plants play an important role in drug discovery, and human beings used them for various purposes from ancient time.

About $80 \%$ of the population in the developing countries depends on medicinal plants for primary health care [3]. Out of 50,000 angiospermic plants used as medicines, more than 600 species are used in Pakistan for curing various diseases $[4,5]$. The family Lamiaceae, also known as Labiatae or mint family, consists of highly valued medicinal plants with cosmopolitan distribution and worldwide source of spices and various extracts [6]. Within this family, about 236 genera and more than 6000 species are present in which genera Ocimum and Mentha provide various taxa [6, 7]. Ethnoecological studies have been carried out by various research studies in Peshawar and adjoining areas [8-14]. The plants of this family contain active chemical constituents and 


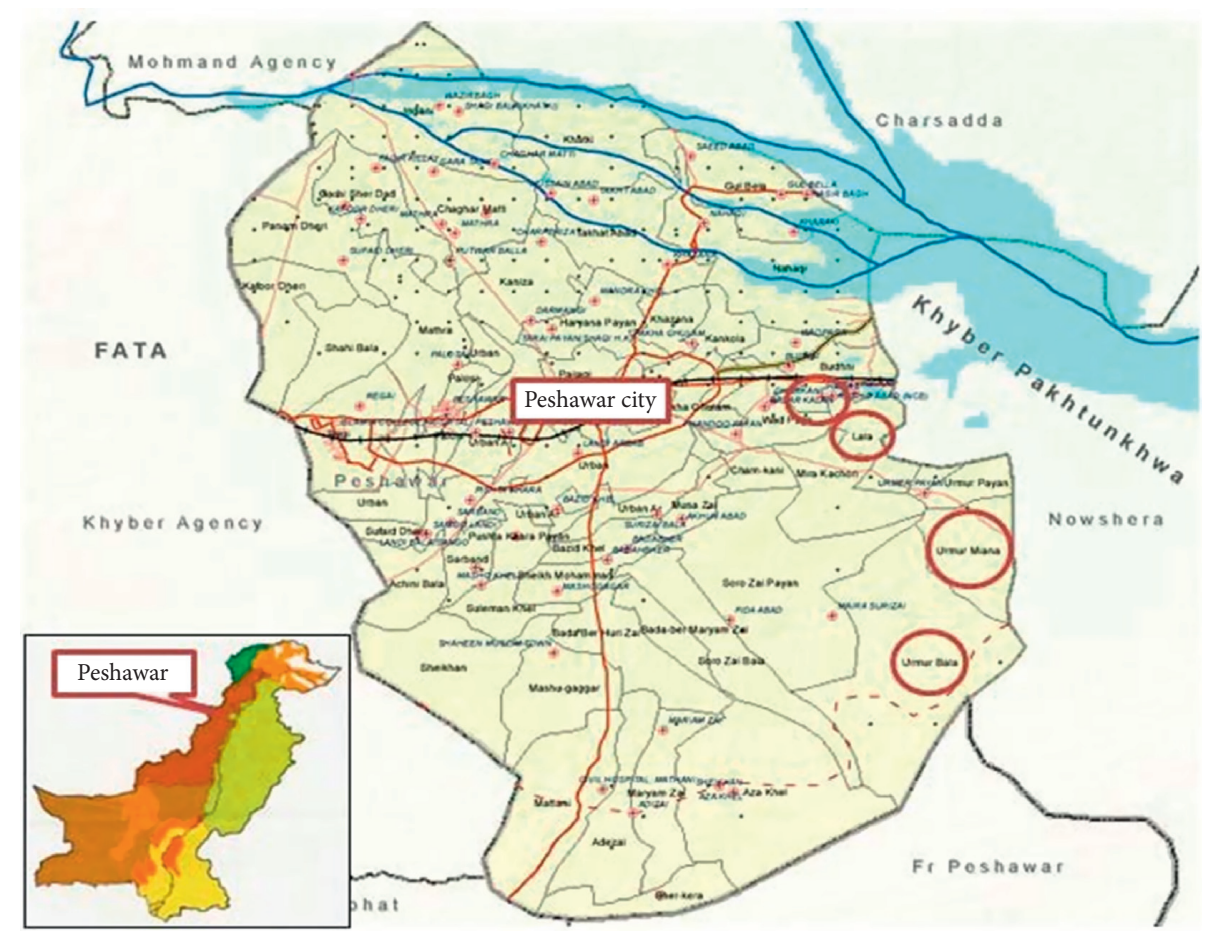

Figure 1: Map of the study area. Source: Geography Department, University of Peshawar, KP, Pakistan.

secondary metabolites like vitamins and minerals [15]. Rosmarinus officinalis is used as an antimicrobial, antiinflammatory, antidiuretic, antidiabetic, and anticancer agent [16]. Mentha species possess antioxidant properties because of the presence of active components, such as rosmarinic acid, menthol, carvone, menthone, and flavonoids [17]. Minerals play a primary role in reproduction, growth, health, and proper functioning of living organisms [18]. Elemental analysis showed that members of Lamiaceae taxa are rich in macro- and microelements. Phytochemicals are naturally occurring biologically active compounds found in plants, which are liable for health benefits of humans $[19,20]$. The phytochemical screening of various plants of Lamiaceae was carried out by Asghari et al., Cocan et al., and Mahendra and Kakde [21-23] and elemental analysis by Arika et al. and Gogoasa et al. $[24,25]$.

The aim of the present work was to evaluate the macroand microelements quantitatively and phytochemical constituents qualitatively. The ecological, ethnobotanical, and ethnomedicinal properties were also known. The findings will help in future research studies.

\section{Materials and Methods}

2.1. Collection of Plants. Fresh leaves of five medicinal plants, M. longifolia, M. piperita, M. spicata, O. basilicum, and $R$. officinalis, were collected from district Peshawar. Plant specimens were taxonomically identified in the Centre of Plant Biodiversity by Dr. Syed Mukaram Shah (PhD), and voucher specimens were deposited in the Herbarium of Department of Botany, University of Peshawar.
2.2. Ecological and Ethnobotanical Profiles. Ecological characteristics of plants depend upon altitude, climate, and related environmental conditions. Life form, leaf size, leaf shape, and phenology of the plants were observed [26-28]. Ethnobotany is the cultural relationship among plants, people, and environment. Ethnobotanical information was gathered through the literature and from the local inhabitants. Ethnomedicinal information was documented from local hakims and aged people.

2.3. Phytochemical Analysis. Leaves were shade-dried for three weeks, grinded into powder using an electrical grinder, and kept in polythene bags with proper labeling for further use. 50 grams of each powder sample were added separately into $250 \mathrm{ml}$ of methanol solvent in a conical flask at room temperature. After 48 hours, the extracts were filtered with Whatman No. 1 filter paper. The extracts were stored in airtight glass at $4^{\circ} \mathrm{C}$ for further analysis.

In test tubes, 0.5 gram of each plant sample was shaken with $5 \mathrm{ml}$ of distilled water. Frothing which persists on warming was taken as preliminary evidence for the presence of saponins [29].

For flavonoid detection, $5 \mathrm{ml}$ of solution of dilute ammonia was mixed with 0.5 gram of the plant sample followed by the addition of concentrated sulphuric acid. Yellow coloration indicates the presence of flavonoids which disappear later on standing [30].

For the detection of terpenoids, $3 \mathrm{ml}$ of concentrated sulphuric acid and $2 \mathrm{ml}$ of chloroform were added to 0.5 gram of the plant sample to form a layer. Reddish-brown coloration showed the presence of terpenoids [31]. 


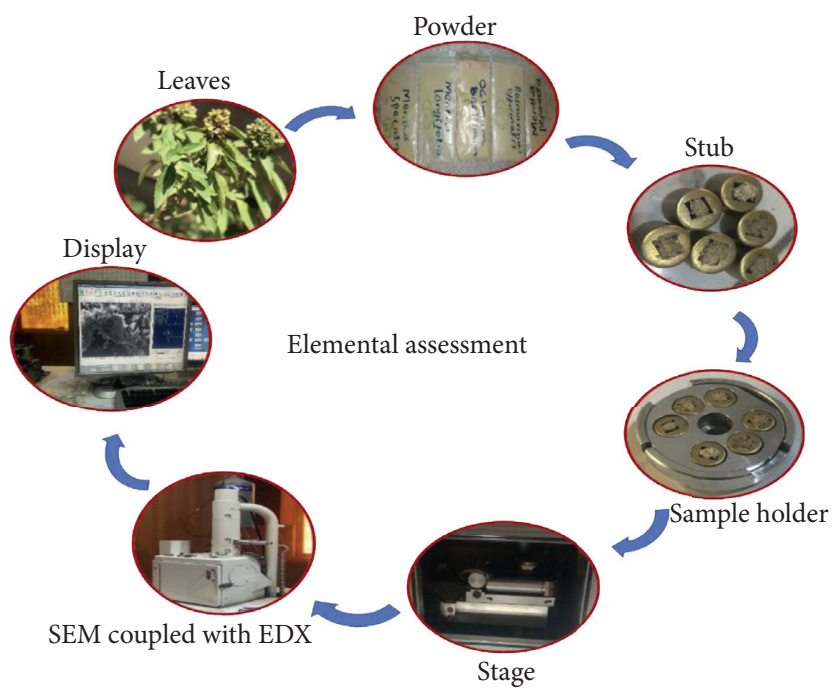

Figure 2: Elemental analysis.

TABLe 1: Biological spectra of plants of Lamiaceae in Peshawar, Pakistan.

\begin{tabular}{|c|c|c|c|c|c|c|}
\hline S. no. & Plant species & Voucher no. & Life form & Leaf size & Leaf shape & Phenology \\
\hline (A) & Angiosperm & & & & & \\
\hline (a) & Dicots & & & & & \\
\hline (1) & Family Lamiaceae & & & & & \\
\hline (1) & Mentha longifolia (L.) Huds. & B.Sul.015.UOP & G & Mic & $S$ & $\mathrm{~S} 1$ \\
\hline (2) & Mentha piperita L. & B.Sul.016.UOP & Th & $\mathrm{N}$ & S & S1 \\
\hline (3) & Mentha spicata L. & B.Sul.017.UOP & Th & $\mathrm{N}$ & $S$ & S1 \\
\hline (4) & Ocimum basilicum L. & B.Sul.018.UOP & Th & Mic & S & S2 \\
\hline (5) & Rosmarinus officinalis L. & B.Sul.019.UOP & $\mathrm{Ch}$ & $\mathrm{N}$ & S & S3 \\
\hline
\end{tabular}

$\mathrm{Ch}=$ chamaephytes,$\quad \mathrm{Th}=$ therophytes, $\mathrm{G}=$ geophytes, $\mathrm{Mic}=$ microphyll, $\mathrm{N}=$ nanophyll,$\quad$ Mes=mesophyll, $\mathrm{S}=$ simple,$\quad \mathrm{S} 1=$ pre-reproductive, $\mathrm{S} 2=$ reproductive, and $\mathrm{S} 3=$ postreproductive.

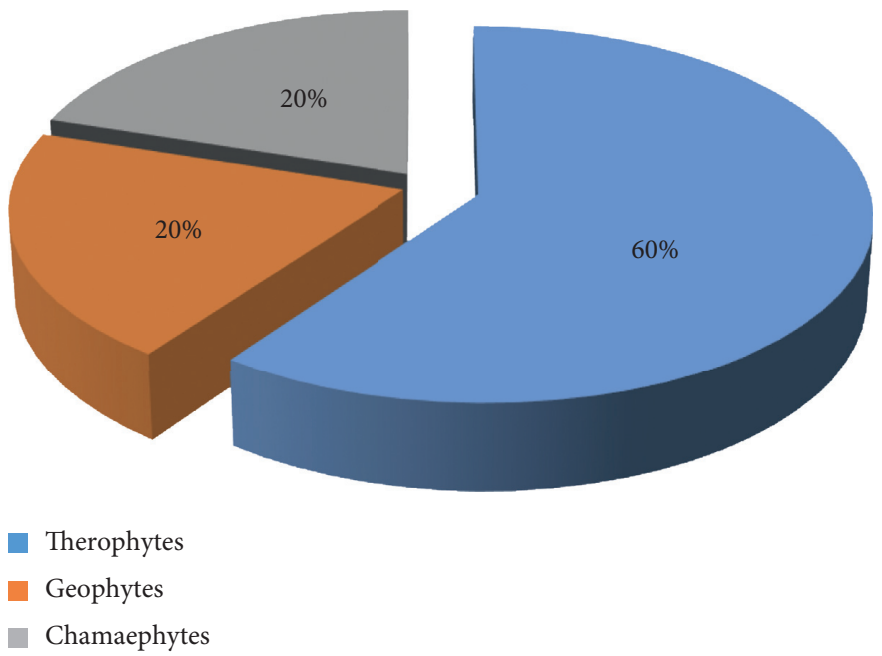

Figure 3: Life-form classes.

For steroid detection, $10 \mathrm{ml}$ of chloroform was mixed with $1 \mathrm{ml}$ of the plant extract, and equal volume of concentrated $\mathrm{H}_{2} \mathrm{SO}_{4}$ was added by the side of the test tube. The upper film turns red, and the $\mathrm{H}_{2} \mathrm{SO}_{4}$ layer shows yellow with green florescence. This indicates the presence of steroids [32].
0.2 gram of each plant powder was boiled in one percent aqueous $\mathrm{HCl}$ solution. The formation of red precipitate indicates the presence of phlobatannins [30,31].

For the detection of tannins, 0.5 gram of each sample was stirred with $100 \mathrm{ml}$ of distilled water, filtered, and 0.1 percent of 
TABle 2: Summary of biological spectra of plant species of Lamiaceae in Peshawar, Pakistan.

\begin{tabular}{|c|c|c|c|}
\hline S. no. & Life-form classes & No. of species & Percentage (\%) \\
\hline \multicolumn{4}{|c|}{ (A) Life form } \\
\hline (i) & Therophytes (Th) & 3 & 60 \\
\hline (ii) & Chamaephytes (Ch) & 1 & 20 \\
\hline (iii) & Geophyte $(\mathrm{G})$ & 1 & 20 \\
\hline Total & & 5 & 100 \\
\hline \multicolumn{4}{|c|}{ (B) Leaf sizes } \\
\hline (i) & Nanophyll & 3 & 60 \\
\hline (ii) & Microphyll & 2 & 40 \\
\hline Total & & 5 & 100 \\
\hline \multicolumn{4}{|c|}{ (C) Leaf shape } \\
\hline (i) & Simple & 5 & 100 \\
\hline Total & & 5 & 100 \\
\hline \multicolumn{4}{|c|}{ (D) Phenology } \\
\hline (i) & Pre-reproductive (S1) & 3 & 60 \\
\hline (ii) & Reproductive (S2) & 1 & 20 \\
\hline (iii) & Postreproductive (S3) & 1 & 20 \\
\hline Total & & 5 & 100 \\
\hline
\end{tabular}

TABle 3: Ethnobotanical profile of plant species of Lamiaceae in Peshawar, Pakistan.

\begin{tabular}{|c|c|c|c|c|}
\hline S. no. & Plant species & (1) & (2) & (3) \\
\hline (1) & Mentha longifolia (L.) Huds. & + & - & + \\
\hline (2) & Mentha piperita L. & + & - & + \\
\hline (3) & Mentha spicata L. & + & + & + \\
\hline (4) & Ocimum basilicum L. & + & + & - \\
\hline (5) & Rosmarinus officinalis L. & + & + & - \\
\hline Total & & 5 & 3 & 3 \\
\hline Percentage (\%) & & 100 & 60 & 60 \\
\hline
\end{tabular}

$(1)=$ medicinal, $(2)=$ ornamental, and $(3)=$ spices.

TAble 4: Ethnomedicinal uses of plants of Lamiaceae in Peshawar, Pakistan.

\begin{tabular}{|c|c|c|c|c|c|c|c|}
\hline \multirow{2}{*}{ S. no. } & \multirow{2}{*}{ Plant species } & \multicolumn{4}{|c|}{ Part used } & \multirow{2}{*}{ Constituents } & \multirow{2}{*}{ Diseases } \\
\hline & & Root & Stem & Leaves & Flower & & \\
\hline (1) & $\begin{array}{l}\text { Mentha longifolia } \\
\text { (L.) Huds. }\end{array}$ & + & + & + & + & $\begin{array}{l}\text { Pulegone, menthone, borneol, and } \\
\text { flavonoids. }\end{array}$ & $\begin{array}{c}\text { Carminative stimulant, antispasmodic, } \\
\text { and headache. }\end{array}$ \\
\hline (2) & Mentha piperita L. & - & - & + & + & $\begin{array}{l}\text { Menthol, menthone, methyl } \\
\text { acetate, and steroids. }\end{array}$ & $\begin{array}{c}\text { Irritable bowel syndrome, muscle pain, } \\
\text { nerve pain, and itching. }\end{array}$ \\
\hline (3) & Mentha spicata L. & - & - & + & - & $\begin{array}{l}\text { Terpenoid, carvone, menthol, } \\
\text { menthone, and tannins. }\end{array}$ & $\begin{array}{c}\text { Antitumor, antioxidant, and } \\
\text { antimicrobial. }\end{array}$ \\
\hline (4) & $\begin{array}{l}\text { Ocimum basilicum } \\
\text { L. }\end{array}$ & + & - & + & + & $\begin{array}{l}\text { Saponins, coumarins, } \\
\text { anthocyanin, and terpenoids. }\end{array}$ & Antioxidant, antifungal, and antiviral. \\
\hline (5) & $\begin{array}{l}\text { Rosmarinus } \\
\text { officinalis L. }\end{array}$ & - & - & + & - & $\begin{array}{l}\text { Rosmarinic acid, camphor, } \\
\text { flavonoids, and saponins. }\end{array}$ & $\begin{array}{l}\text { Antioxidant, antidiuretic, and anti- } \\
\text { inflammatory. }\end{array}$ \\
\hline
\end{tabular}

ferric chloride reagent was added to the $20 \mathrm{ml}$ filtrate. The appearance of blue-green coloration shows the presence of tannins [33].

For anthraquinone detection, 0.5 gram of the plant extract was shaken with $5 \mathrm{ml}$ of chloroform. The solution was filtered, and 10 percent ammonia solution was added to the filtrate. The mixture was shaken thoroughly, and the formation of pink/violet color in the ammonical phase indicates the presence of anthraquinones [31].
2.4. Elemental Analysis. Plants were collected, shade-dried, and ground to powder. For the quantitative analysis of macro- and microelements, energy-dispersive X-ray spectrometer (Model Perkin Elmer AA Analyst 700) was used which is installed in the Centralized Resource Laboratory, University of Peshawar. 0.5 gram of each plant powder was placed on stub, which was grip in the sample holder. The sample holder was laid inside the stage, and the elements' peaks were observed through display (Figure 2). 
TABLe 5: Mineral contents in plant species of Lamiaceae in Peshawar, Pakistan.

\begin{tabular}{|c|c|c|c|c|c|c|c|c|c|c|c|c|c|c|}
\hline \multirow{3}{*}{ S. no. } & \multirow{3}{*}{ Plant species } & \multicolumn{13}{|c|}{ Minerals (\%) } \\
\hline & & \multicolumn{5}{|c|}{ Major elements } & \multicolumn{8}{|c|}{ Minor elements } \\
\hline & & $\mathrm{C}$ & $\mathrm{N}$ & $\mathrm{O}$ & $\mathrm{Mg}$ & $\mathrm{K}$ & $\mathrm{P}$ & S & $\mathrm{Ca}$ & $\mathrm{Al}$ & $\mathrm{Si}$ & $\mathrm{Fe}$ & $\mathrm{Cl}$ & $\mathrm{Na}$ \\
\hline (1) & Mentha longifolia (L.) Huds. & 60.19 & 7.74 & 34.07 & 0.37 & 5.90 & 0.40 & 0.61 & 2.30 & - & 0.61 & - & 0.54 & - \\
\hline (2) & Mentha piperita $\mathrm{L}$. & 56.26 & 7.89 & 36.42 & 0.38 & 4.01 & 0.59 & 0.40 & 1.53 & 0.17 & 0.54 & 0.24 & 0.50 & - \\
\hline (3) & Mentha spicata L. & 56.69 & 8.23 & 33.90 & 0.39 & 3.41 & 0.59 & 0.76 & 2.01 & 0.31 & 0.93 & 0.29 & 1.09 & 0.39 \\
\hline (4) & Ocimum basilicum L. & 57.59 & 9.78 & 33.72 & 0.58 & 4.46 & 0.46 & 0.52 & 2.67 & 0.25 & 0.75 & 0.17 & 0.89 & - \\
\hline (5) & Rosmarinus officinalis L. & 70.25 & - & 29.91 & 0.27 & 2.15 & 0.27 & 0.28 & 1.05 & 0.14 & 0.40 & - & 0.19 & - \\
\hline
\end{tabular}

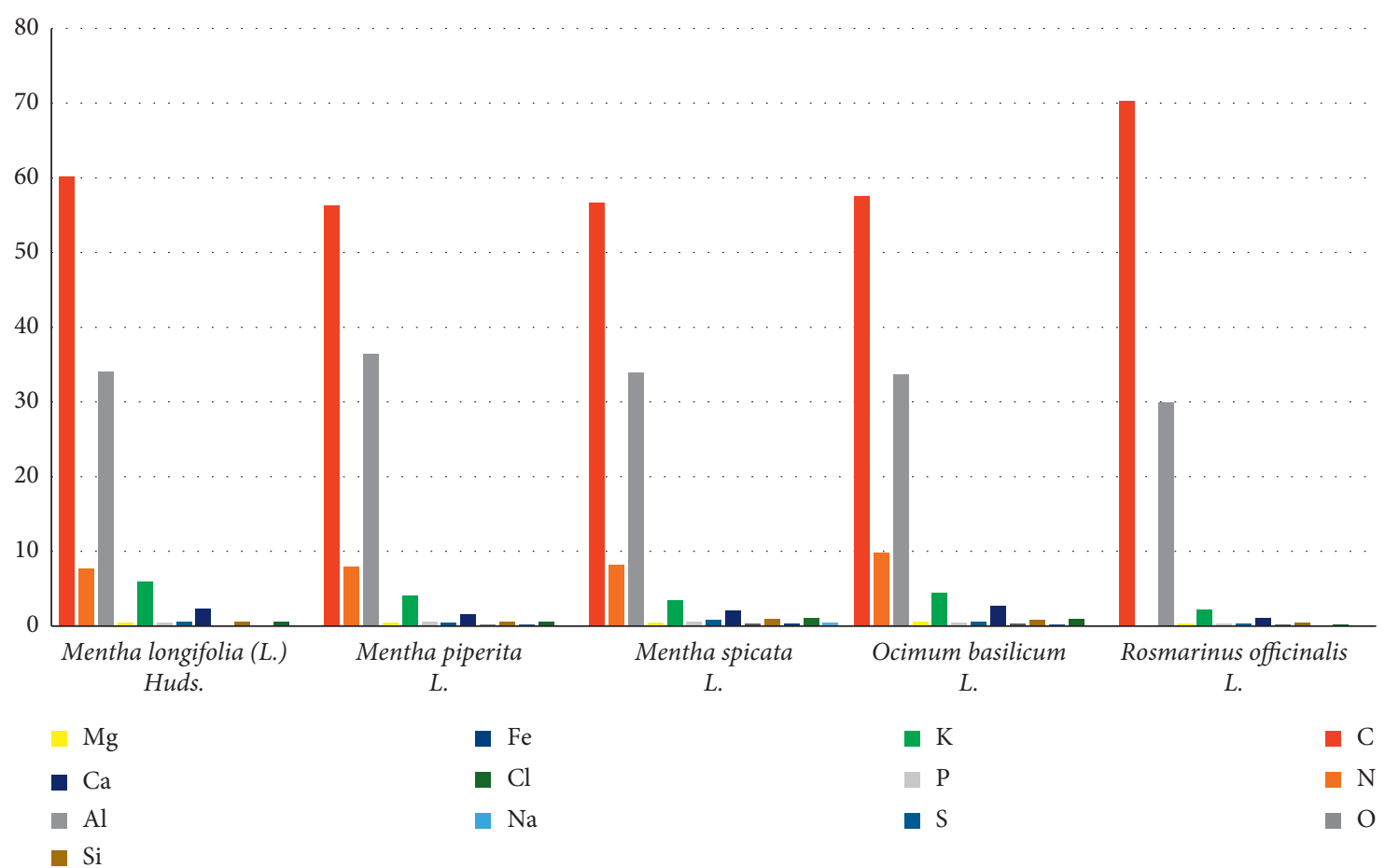

Figure 4: Elemental assessment of plant species: (a) Mentha spicata L.; (b) Mentha longifolia (L.) Huds.; (c) Rosmarinus officinalis L.; (d) Mentha piperita L.; (e) Ocimum basilicum L.

Quantitative results obtained were copied to an Excel worksheet. The worksheet was referred to as raw data. All the data in the raw data worksheet were copied to an edited worksheet where unnecessary data columns were deleted. Also, unnecessary element row lines were removed, leaving the calculated averages as the final concentration data.

\section{Results and Discussion}

3.1. Ecological and Ethnobotanical Profiles. During the present research work, 5 plant species of Lamiaceae were collected from the study area which were investigated for their various biological aspects such as phenology, life form, leaf shape, leaf size, and ethnobotanical uses along with phytochemical and elemental screening. During collection time, the phenological stage of Mentha species was prereproductive, while Ocimum and Rosmarinus were at reproductive and postreproductive stages (Table 1). Sixty percent species were therophytes, and $20 \%$ were each chamaephytes and geophytes (Figure 3). The biological leaf spectra showed that $60 \%$ species had nanophyllous and $40 \%$ had microphyllous leaves (Table 2). All the species had a simple leaf shape. Ethnobotanical profile showed that a majority of plant species were used in spices and had medicinal and ornamental importance (Table 3). Various parts of the plants contained active constituents such as menthol, menthone, and rosmarinic acids which are used as antifungal, antioxidant, anti-inflammatory, and antidiuretic agents (Table 4). The present work agrees with many other research studies [17, 34], where both reported that these species were used as antioxidant, antidiuretic, and antimicrobial agents.

3.2. Macro- and Microelements' Assessment. All the plant species had high mineral contents and can be used as a good source for medicines (Table 5). A total of 13 different elements were quantitatively analyzed in all the five plant species. Among the major elements, carbon was maximum $(70.25 \%)$ in $R$. officinalis and minimum $(56.2 \%)$ in 


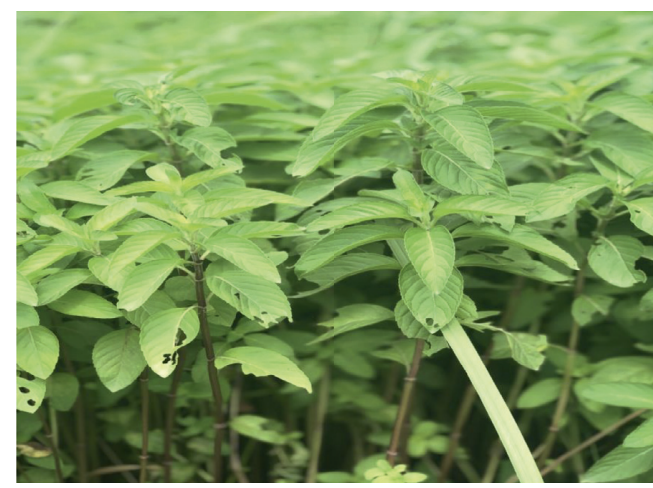

(a)

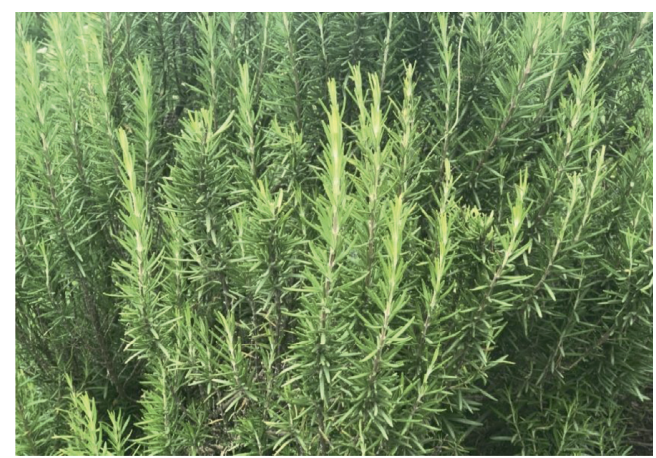

(c)

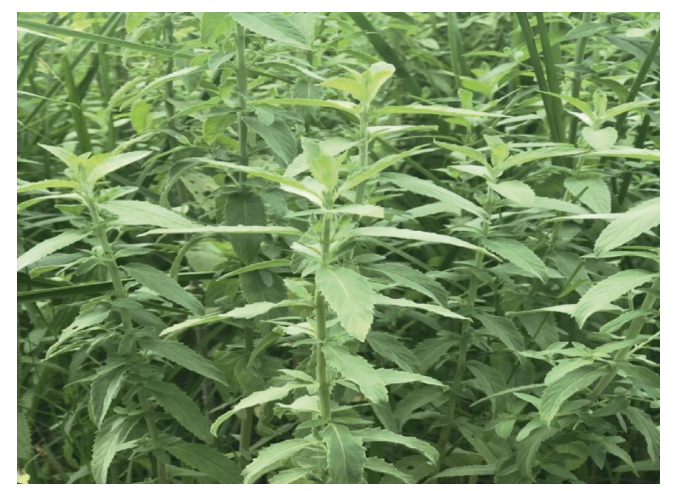

(b)

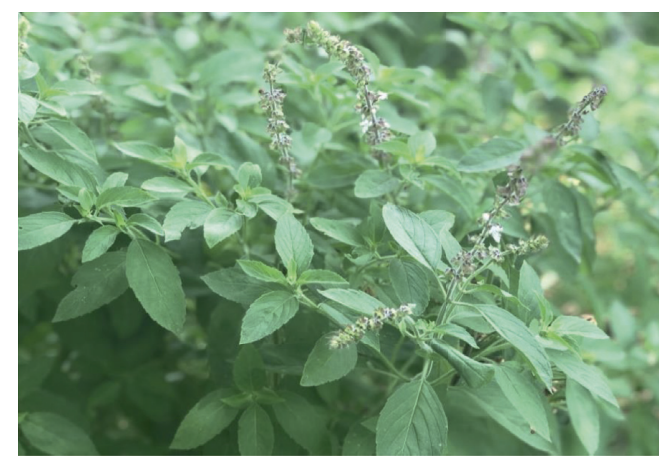

(d)

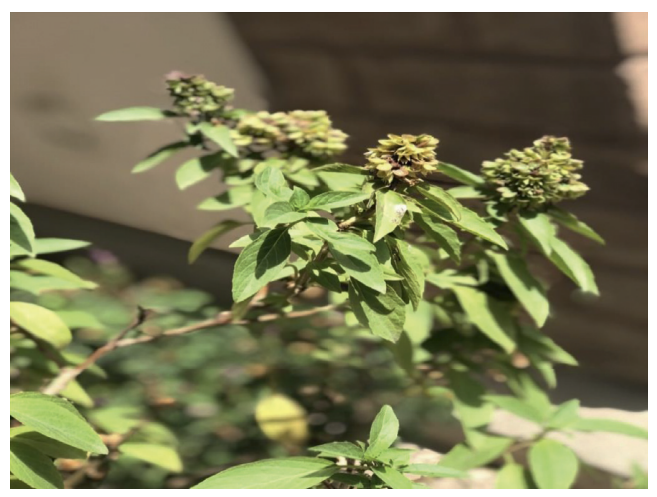

(e)

Figure 5: Mentha spp.

TABle 6: Phytochemical screening of plants of Lamiaceae in Peshawar, Pakistan.

\begin{tabular}{lcccccccc}
\hline S. no. & Plants species & Flavonoids & Steroids & Tannins & Terpenoids & Saponins & Phlobatannins & Anthraquinones \\
\hline$(1)$ & Mentha longifolia (L.) Huds. & + & - & - & + & + & - & - \\
$(2)$ & Mentha piperita L. & + & + & + & - & + & - & - \\
$(3)$ & Mentha spicata L. & - & + & + & + & - & + & - \\
$(4)$ & Ocimum basilicum L. & + & + & - & + & + & - & + \\
$(5)$ & Rosmarinus officinalis L. & + & - & + & + & + & - & - \\
\hline
\end{tabular}

M. piperita, while only nitrogen was absent in R. officinalis. In minor elements, chlorine was found highest $(1.09 \%)$ in Mentha spicata and lowest (0.19\%) in R. officinalis (Figures 4 and 5). O. basilicum and $M$. longifolia had high calcium content which plays a key role in bone formation [35]. M. longifolia had the highest potassium concentration which plays a key part of many enzymes' synthesis and plays a vital role in the activation of growth of enzymes [36, 37]. Arika et al. [24] and Gogoasa et al. [25] had reported $\mathrm{C}, \mathrm{N}, \mathrm{O}, \mathrm{Mg}, \mathrm{K}, \mathrm{P}, \mathrm{S}, \mathrm{Ca}, \mathrm{Al}, \mathrm{Si}, \mathrm{Fe}, \mathrm{Cl}$, and $\mathrm{Na}$ elements in Mentha species, Ocimum species, and in Rosmarinus species. 
3.3. Phytochemical Screening. The phytochemical tests of plant extracts were determined for the presence of flavonoids, saponins, phlobatannins, tannins, steroids, terpenoids, and anthraquinones (Table 6). The results showed that the majority of the plants contained flavonoids, terpenoids, and saponins, while anthraquinones were only present in $O$. basilicum. The extract of $M$. piperita and $R$. officinalis contained flavonoids which are used in various ailments including dyspepsia, renal pain, arthritis, and antitumor [38]. Steroids were present in most plant extracts which are of great importance in pharmacy because they possess compounds like sex hormones [39]. The finding agrees with that of Adham [6] and Inas et al. [32], who also observed flavonoids, phlobatannins, saponins, terpenoids, tannins, steroids, and anthraquinones in these species.

\section{Conclusions}

The use of medicinal plants is a traditional practice in Pakistan; thus, it is very important to evaluate the therapeutic use of plants through scientific methods and provide information about the species that could be used in the future for their properties. The medicinal plants appear to be rich in secondary metabolites and mineral contents, widely used in traditional medicine to combat and cure various diseases. The selected five species in this study consist of many useful phytochemical compounds and active elements having important biological properties. Phytochemical investigation and elemental analysis of $M$. longifolia, M. piperita, M. spicata, O. basilicum, and R. officinalis showed significant results and may be used for curing of different ailments and manufacturing of new drugs in the future.

\section{Data Availability}

The data used to support the findings of this study are included within the article.

\section{Conflicts of Interest}

The authors declare that there are no conflicts of interest regarding the publication of this paper.

\section{Acknowledgments}

The authors are indebted to Dr. Syed Mukaram Shah of Centre of Plant Biodiversity, University of Peshawar, Peshawar, for his supervision and proofreading the article.

\section{References}

[1] Pakistan Bureau of Statistics, District Census Report, Peshawar, Department of Statistics, Pakistan Bureau of Statistics, Khyber Pakhtunkhwa, Pakistan, 1998.

[2] R. Mehmood, S. A. Mehmood, M. A. Butt, I. Younas, and M. Adrees, "Spatiotemporal analysis of urban sprawl and its contributions to climate and environment of peshawar using remote sensing and GIS techniques," Journal of Geographic Information System, vol. 8, no. 2, pp. 137-148, 2016.
[3] World Health Organization, Diarrhoeal Disease, World Health Organization, Geneva, Switzerland, 2013, http://www. who.int/mediacentre/factsheets/fs330/en/.

[4] Z. K. Shinwari, "Medicinal plants research in Pakistan," Journal of Medicinal Plants Research, vol. 4, no. 3, pp. 161-176, 2010.

[5] Z. Waris, Y. Iqbal, A. Hussain et al., "Proximate composition, phytochemical analysis and antioxidant capacity of Aloe vera, Cannabis sativa and Mentha longifolia," Pure and Applied Biology, vol. 7, no. 3, pp. 1122-1130, 2018.

[6] A. N. Adham, "Comparative extraction methods, phytochemical constituents, fluorescence analysis and HPLC validation of rosmarinic acid content in Mentha piperita, Mentha longifolia and Osimum basilicum," Journal of Pharmacognosy and Phytochemistry, vol. 3, no. 6, pp. 130-139, 2015.

[7] K. C. Stanko, M. Petek, and M. Grdisa, ““'Medicinal plants of the family Lamiaceae as functional foods-a review," Czech Journal of Food Sciences, vol. 34, no. 5, pp. 377-390, 2016.

[8] F. Hadi, N. Ahmad, A. Rashid, and S. Farooq, "A checklist of phanerogamic flora at Haripur Hazara, K. P., Pakistan," Pakistan Journal of Botany, vol. 42, no. 3, pp. 1511-1522, 2010.

[9] F. Hussain, I. Iqbal, and M. F. Durrani, "Vegetation studies on Ghalegay hills, district Swat, Pakistan," Pakistan Journal of Plant Science, vol. 30, pp. 1-10, 2000.

[10] M. Ilyas, Z. K. Shinwari, and R. Qureshi, "Vegetation composition and threats to the Montane temperate forest ecosystem at Qalagai hills, Swat, KPK, Pakistan," Pakistan Journal of Botany, vol. 44, pp. 113-122, 2012.

[11] D. Khan and R. Ahmad, "Floristics, life-form, leaf-size and halo-physiotypic spectra of coastal Flora of Pakistan," in Proceedings of the National Conference-Problems and Resources of Pakistan and Plan of Action for its Development, PCST, Islamabad, Pakistan, pp. 158-189, 1992.

[12] M. Khan, F. Hussain, and S. Musharaf, "Floristic composition and biological characteristics of the vegetation of sheika Multon town, district Mardan, Pakistan," Annual Review and Research in Biology, vol. 3, no. 1, pp. 31-41, 2013.

[13] M. Khan, F. Hussain, S. Musharaf, and I. Ullah, "Floristic composition, life form, leaf size spectra of the coal mine area vegetation of Darra Adam Khel, KP, Pakistan," Journal of Biodiversity and Environmental Sciences, vol. 1, no. 3, pp. 1-6, 2011.

[14] K. S. Marwat, K. Usman, R. A. Shah, A. Shah, and E. A. Khan, "Floristic account at emergent-aquatic and marsh land, Angiosperm at D. I. Khan District KP, Pakistan," Pakistan Journal of Botany, vol. 45, pp. 279-288, 2013.

[15] H. Davidson, "Ecological ethnobotany: stumbling toward new practices and paradigms," Model Assisted Statistics and Applications Journal, vol. 16, pp. 1-13, 2000.

[16] I. B. Linares, K. C. Stojanovic, R. Q. Pine et al., "Rosmarinus officinalis leaves as a natural source of bioactive compounds," International Journal of Molecular Sciences, vol. 15, pp. 20585-20606, 2014.

[17] E. Padmini, A. M. Valarmathi, and U. Rani, "Comparative analysis of chemical composition and antibacterial activities of Mentha spicata and Camella sinensis," Asian Journal of Experimental Biological Sciences, vol. 1, no. 4, pp. 772-781, 2010.

[18] Z. Sher, F. Hussain, and M. Saleem, “"Macro-mineral status at three phenological stages of some range shrubs of Gadoon hills, district Swabi, Khyber Pukhtunkhwa, Pakistan," Pakistan Journal of Botany, vol. 44, no. 2, pp. 711-716, 2012.

[19] C. M. Hasler and J. B. Blumberg, "Introduction," The Journal of Nutrition, vol. 129, no. 3, pp. 756S-757S, 1999. 
[20] S. Ullah, G. Jan, F. Gul et al., "Phytochemical and nutritional analysis of selected plants of district Buner Pakistan," International Journal of Fauna and Biological Studies, vol. 5, no. 3, pp. 111-117, 2018.

[21] G. Asghari, M. Akbari, and M. Asadi-Samani, "Phytochemical analysis of some plants from Lamiaceae family frequently used in folk medicine in Aligudarz region of Lorestan province," Marmara Pharmaceutical Journal, vol. 21, no. 3, p. 506, 2017.

[22] C. Cocan, E. Alexa, C. Danciu et al., "Phytochemical screening and biological activity of Lamiaceae family plant extracts," Experimental and Therapeutic Medicine, vol. 15, pp. 18631870, 2018.

[23] S. S. Mahendra and N. P. Kakde, "Phytochemical analysis of some plants of family Lamiaceae occurring in local area of Deulgaon Raja," International Journal of Academic Research and Development, vol. 3, no. 2, pp. 1352-1354, 2018.

[24] W. M. Arika, P. E. Ogola, D. W. Nyamai, A. M. Mawia, and F. K. Wambua, "Mineral elements content of selected Kenyan antidiabetic medicinal plants," Advanced Techniques in Biology and Medicine, vol. 4, p. 160, 2016.

[25] I. Gogoasa, J. Violeta, A. L. Maria et al., "Mineral content of some medicinal herbs," Journal of Horticulture, Forestry and Biotechnology, vol. 17, no. 4, pp. 65-67, 2013.

[26] F. Hussain, Field and Laboratory Manual of Plant Ecology, UGC, Islamabad, Pakistan, 1989.

[27] F. Hussain, S. M. Shah, L. Badshah, and M. J. Durrani, "Diversity and ecological characteristics of flora of Mastuj valley, district Chitral, Hindukush range, Pakistan," Pakistan Journal of Botany, vol. 47, no. 2, pp. 495-510, 2015.

[28] C. C. Raunkiaer, The Life Form of Plants and Statistical Plant Geography, Oxford University Press, London, UK, 1934.

[29] B. O. Obadoni and P. O. Ochuko, "Phytochemical studies and comparative efficacy of the crude extracts of some homeostatic plants in edo and delta states of Nigeria," Global Journal of Pure and Applied Science, vol. 8, pp. 203-208, 2001.

[30] A. Sofowora, "Recent trends in research into African medicinal plants," Journal of Ethnopharmacology, vol. 38, no. 2-3, pp. 197-208, 1993.

[31] J. B. Harborne, Phenolic Compounds. Phytochemical Methods, Vol. 5, Springer, Berlin, Germany, 1973.

[32] M. Inas, Khamis, and A. A. Ahmed, "Preliminary phytochemical screening of different solvent extracts of some medicinal plants," Middle East Journal of Applied Science, vol. 7, no. 2, pp. 226-231, 2017.

[33] G. E. Trease and W. C. Evans, Pharmacognosy, Macmillan Publishers, London, UK, 11th edition, 1989.

[34] J. Javanmardi, A. Khalighi, H. P. Bais, and J. M. Vivanco, "Chemical characterization of basil (Ocimum basilicum L.) found in local accessions and used in traditional medicines in Iran," Journal of Agricultural and Food Chemistry, vol. 50, no. 21 , pp. 5878-5883, 2002.

[35] R. Khan, M. N. Khan, H. Ullah et al., "A comparative assessment of proximate and elemental composition six weedy grasses for their potential use as fodder," Progress in Nutrition, vol. 20, no. 1, pp. 182-190, 2017.

[36] M. Khan, F. Hussain, and S. Musharaf, "Macro-mineral contents in ten species at three phenological stages in Tehsil Takhte- Nasrati, District Karak, Pakistan," African Journal of Agriculture Research, vol. 8, no. 6, pp. 5475-5484, 2013.

[37] J. Sultan, R. I. Urinam, M. Yaqoob, H. Nawaz, and M. Hameed, "Nutritive value of free rangeland grasses of northern grasslands of Pakistan," Pakistan Journal of Botany, vol. 40, pp. 249-258, 2008.
[38] D. O. Okach, A. R. O. Nyunja, and G. Opende, "Phytochemical screening of some wild Plants forms Lamiaceae and their role in traditional medicine in Uriri District-Kenya," International Journal of Herbal Medicine, vol. 1, pp. 135-143, 2013.

[39] D. E. Okwu, "Evaluation of the chemical composition of indigenous spices and flavoring agents," Global Journal of Pure and Applied Sciences, vol. 7, no. 3, pp. 455-459, 2001. 